\title{
Retinal Dehydrogenase 2
}

National Cancer Institute

\section{Source}

National Cancer Institute. Retinal Dehydrogenase 2. NCI Thesaurus. Code C21330.

Retinal dehydrogenase $2(518 \mathrm{aa}, \sim 57 \mathrm{kDa}$ ) is encoded by the human ALDH1A2 gene.

This protein plays a role in retinol metabolism. 